\section{Measuring the value of internal audit in the banking industry}

Clara-Iulia ZINCA (VOICULESCU), Bucharest University of Economic Studies, E-Mail: iulia.voiculescu@gmail.com

\section{Alsstract}

The importance of the audit function in banking institutions has considerably increased during the financial crisis, the focus of the management moving to risk management and control processes. The role of internal audit is to help management in protecting the bank's patrimony, reputation and ensuring the sustainable development of the organization, by providing an extensive analysis and a comprehensive insight on activities. Furthermore, just as each department must achieve the set objectives and add value to the organization, the same is true for the internal audit department.

This study aims to examine the methods used to measure the value of internal audit in the banking industry and to identify the most significant methods that consider the effect of the internal audit results on the organization.

We propose answers to questions such as: "Do audit functions in banking institutions confirm their value?" and "How can internal audit demonstrate its contribution to adding value to the organization?" In this regard, we approached the measuring of the internal audit value from a theoretical point of view. Further, we investigated which are metrics (KPIs) and practices used to measure the value of internal audit and analysed the extent to which these metrics are likely to highlight the value added to the organization by the internal audit activity. The results of the study suggest that most organizations use methods that contain mainly quantitative and less qualitative elements. There are differences between banks and other types of organizations in terms of the methods and practices used, but also on the importance showed to measurement of internal audit value. In addition, the findings confirm that there is room for improving the methods and practices used, so that the audit function gains value and credibility.

Keywords: Internal audit, value added, performance measurement, banks.

JEL Classification: G21, M42.

To cite this article:

Zinca (Voiculescu), C.I. (2016), Measuring the value of internal audit in the banking industry, Audit Financiar, vol. XIV, no. 9(141)/2016, pp. 1009-1024, DOI: 10.20869/AUDITF/2016/141/1009

To link to this article:

http://dx.doi.org/10.20869/AUDITF/2016/141/1009 


\section{introduction}

The global financial crisis has demonstrated the need to revise certain functions whose performance is important for the healthy functioning of the banking system, one of these functions being represented by internal audit, which must respond to new challenges, changes and expectations.

During the current period, banking institutions face a dynamic and challenging environment, where they must comply with new regulatory requirements, strengthen corporate governance and expand their offer of products and services. Most banking institutions had no option but to seek solutions in order to achieve a balance between managing risk, maximizing profitability and ensuring the observance of applicable regulations.

Although the internal audit function is not directly responsible for the identification of solutions to the problems faced by banking institutions, it has an important role, supporting the organization in achieving and maintaining the necessary balance, by providing evaluations of the internal control environment and recommendations leading to the improvement of risk management processes and the assurance of compliance with regulations.

Under these circumstances, internal auditors have not only the opportunity, but also the responsibility to support the management, by proactively involving in finding solutions to the problems of the organization and by providing recommendations and support to the business lines, management and the audit committee.

These developments are also reflected by the modifications occurred over time in the definitions of the internal audit function provided by the Institute of Internal Auditors (IIA), presented in Table 1.

\section{Table 1. The evolution of internal audit definitions provided by the IIA}

The old definition of internal audit (released in 1947, revised in 1999)

"Internal Audit is an independent appraisal function established within an organization to examine and evaluate its activities as a service to the organization. The objective of internal audit is to assist members of the organization in the effective discharge of their responsibilities. To the end, internal audit furnishes them with analyses, appraisals, recommendations, counsel and information concerning activities reviewed. The audit objective includes promoting effective control at reasonable cost. The members of the organization assisted by internal auditing include those in management and the board of directors."
The current definition of internal audit (released in 1999)

"Internal auditing is an independent, objective assurance and consulting activity designed to add value and improve an organization's operations. It helps an organization accomplish its objectives by bringing a systematic, disciplined approach to evaluate and improve the effectiveness of risk management, control and governance processes."

Source: Author's processing of definitions provided by the IIA, 1947; IIA, 1999

According to the most recent definition developed by the IIA (1999) and approved by the IIA Board of Directors in
1999, some important developments can be noted, which are highlighted in Table 2.

Table 2. Differences in the definition of internal audit

\begin{tabular}{|l|l|}
\multicolumn{1}{|c|}{ The old definition (before 1999) } & \multicolumn{1}{c|}{ The current definition (after 1999) } \\
\hline Appraisal function & Objective assurance and consulting activity \\
\hline $\begin{array}{l}\text { Examines and evaluates the activities, as a service for the } \\
\text { organization }\end{array}$ & $\begin{array}{l}\text { Adds value and stimulates improving the organization's } \\
\text { activities }\end{array}$ \\
\hline $\begin{array}{l}\text { Assists members of the organization in the effective discharge of } \\
\text { their responsibilities }\end{array}$ & $\begin{array}{l}\text { Assist the organization in fulfilling its objectives through a } \\
\text { systematic and disciplined approach }\end{array}$ \\
\hline Promotes effective control at a reasonable cost & $\begin{array}{l}\text { Evaluates and improves the effectiveness of risk } \\
\text { management, control and governance processes. }\end{array}$ \\
\hline
\end{tabular}

Source: Author's processing 
The revised definition of internal audit emphasizes the objective of internal audit, which is to add value to the organization and activate the improvement of its activities through the provided objective assurance and advisory services.

In the guide "The internal audit function in banks" (BCBS, 2012), The Basel Committee on Banking Supervision (BCBS) highlights the fact that the internal audit function must provide the bank's board of directors and senior management with assurance in regard to the quality of the internal control system, thus reducing the risks of loss and reputational damage for the bank. At the same time, the bank's supervisors must be content with the effectiveness of the bank's internal audit function regarding the compliance with policies and practices and the adoption by the management of appropriate and prompt measures in order to remedy the internal control deficiencies identified by internal audit.

The conclusions drawn from various studies carried out recently (Global Audit Information Network - GAIN, 2009; PriceWaterhouseCoopers - PwC, 2014a, 2014b; Ernst \& Young, 2010; Deloitte, 2014) highlight the major challenges faced by internal audit in terms of expanding its role, given multiple emergent risks, rising of expectations and stronger stakeholder scrutiny, as well as resources pressures. To overcome these difficulties, it is necessary for the internal audit function to develop the core competencies, approaches, tools and practices, which enable the increase of value added for the organization.

Both Chief Audit Executives (CAEs), as well as stakeholders, recognize the potential of the internal audit function to add value to the organization. The important positive contribution that internal audit can bring in governance and operations of an organization depends on the effective implementation, functioning and management of the internal audit function, which is possible only under the conditions of maintaining and strengthening its credibility.

In order to maintain and increase the credibility and authority of internal audit, the internal auditors should:

- Understand how the organization perceives audit value;

- Define a strategic audit plan appropriate for the mandate of the internal audit function, containing the established objectives which prove the value delivered to the organization;

- Measure the value and performance of internal audit;
- Properly communicate the achieved results.

Since the stakeholders' expectations have permanently increased, the management of the audit function had to adapt their practices to keep pace with these expectations and to adjust the metrics used to track results and report performance.

\section{Methodology of research}

The research methodology employed for the development of this paper included the following elements:

- A review of the international literature, including the applicable regulations and recommendations (IIA, $B C B S$ ) on internal audit in general and on internal audit in the banking industry. The revision considered the various aspects of internal audit, such as: the role and the objectives of internal audit; the responsibilities incumbent upon the internal audit function in different areas of activity such as compliance, risk management, reducing strategic risk, improving strategic management activity (business improvement); value added and assessment of performance of the internal audit activity; ways in which internal audit can exceed its current role and become a strategic advisor.

- A review of the research projects' results and case studies including: "Imperatives for Change: The IIA's Global Internal Audit Survey in Action. Report V" (IIA, 2011c); studies and reports developed by companies of professional services and consulting (Ernst\&Young, 2010; PwC, 2014a, 2014b; Deloitte, 2014).

By performing a critical analysis of the reviewed literature, research results and studies, we aimed to answer the following questions:

- What would be the most relevant indicators for tracking results and for reporting the performance of the internal audit activities, so that the audit function demonstrates the added value for the organization?

- What are the methods and practices by which internal audit can increase the added value for the organization?

Finally, we synthesized the relevant methods and practices for internal audit performance measurement in the banking sector. 
2. Literature review regarding the value added and internal audit

\subsection{The position of internal audit within the corporate governance of credit institutions}

Directive 2006/48/EC of the European Parliament and of the Council of 14 June 2006 relating to the taking up and pursuit of the business of credit institutions (Article 22) requires each credit institution to set a sound governance framework, which includes an articulated organisational structure with clearly defined, transparent and solid responsibility lines, as well as effective processes for identifying, managing, monitoring and reporting of the risks to which it is or might be exposed, appropriate internal control mechanisms, reliable administrative and accounting procedures, in accordance with the promotion of an efficient and healthy risk management.

Considering the fact that strong corporate governance constitutes an essential condition for the healthy functioning of credit institutions, which at the same time may negatively affect the bank's risk profile without appropriate implementation, supervisory authorities have a strong interest in ensuring a sound corporate governance.

In this regard, the supervisory authorities assess the extent to which the credit institution has set mechanisms through which the board and the superior management achieve their supervisory responsibilities, as well as processes through which it carries out the monitoring of strategic objectives, including risk appetites, financial performance, capital adequacy and planning, liquidity, risk profile and risk cultures, controls, remuneration practices and management selection and evaluation. Special attention is paid to the supervision of risk management, compliance and internal audit functions, the supervisory authorities pursuing the degree to which internal controls are properly assessed and contribute to the sound governance of the bank.

Internal audit has a very important role within the corporate governance framework of credit institutions. In this respect, the "Corporate Governance Principles for Banks" (BCBS, 2015) stipulate internal audit's responsibility with respect to the provision of independent assurance and support to the board and senior management in promoting corporate governance process and the long-term stability of the bank.

The Guide (BCBS, 2015) also highlights the need that the corporate governance framework to establish clear responsibilities relating to managing risk, assigned to the "three lines of defence" of the governance framework, as follows:

- The first line of defence is represented by business units, which accept and manage the risk involved in the activities they carry out;

- The second line of defence, independent of the first one, includes the risk management and compliance functions;

- The third line of defence, independent of the first two, is the internal audit function, which provides the board and senior management with independent review and objective assurance on the quality and effectiveness of the internal control, risk management and corporate governance systems and processes, helping the board to secure the organization and its reputation.

\subsection{The role of internal audit regarding the improvement of the internal control and risk management}

The guide prepared by the BCSB (2015) - "Corporate governance principles for banks defines the internal control system as a set of rules and controls regulating the bank's organisational and operational systems, including reporting, processes and risk management, compliance and internal audit functions.

In line with the requirements stipulated by the applicable banking regulations in the EU Member States, the Government Ordinance No. 99/2006 regarding credit institutions and capital adequacy grants maximum importance to internal control. Thus, the Ordinance stipulates that the internal control mechanisms of credit institutions shall be established by their incorporation acts and internal regulations and that they must provide at least the organization of risk management, compliance and internal audit functions.

The general framework for the implementation of internal control activity in the banking industry was first synthesized by the BCBS (1998) in the guide "Framework for Internal Control Systems in Banking Organisations". 
According to this guide (BCBS, 1998), internal control is a continuous process conducted by the board of directors, managers and staff at all credit institutions' levels, having as main objectives:

a. Conducting the credit institution's activities in an efficient and effective manner;

b. Providing credible, complete and timely financial and management information;

c. Ensuring the conformity of the credit institution's activities with the legal framework and the applicable regulations.

In order to achieve the set objectives and ensure financial stability, credit institutions are required to implement an internal control system which is composed of the following five elements, placed in close correlation:

a. Oversight carried out by the management and the control culture within the organization;

b. Risks identification and assessment;

c. Control activities and separation of responsibilities;

d. Information and communication;

e. Monitoring activities and correcting the detected deficiencies.

The final responsibility for the establishment and maintenance of an adequate and effective internal control system belongs to the credit institution's board of directors.

The internal audit function meets an important role and adds value to the organization by providing the board with an independent review and objective assurance as to the quality and effectiveness of the internal control systems and processes and by supporting the management with regard to the establishment and maintenance of an adequate and efficient internal control system.

Therefore, one of the main objectives of internal audit is to assess the effectiveness and the adequacy of the internal control system, of which it is part.

Over the past decade, credit institutions have experienced an unprecedented escalation of risk, which has caused major changes governance with regard to risk management and improvement of the approaches within the control systems.

Banking risks express the probability of failure to achieve the estimated result or to record a loss, considering that when the respective risks become reality, unexpected results may occur.

The National Bank of Romania (Banca Națională a României - BNR) Regulation No. 5 of December 20, 2013 regarding the administration framework of credit institution's activity, the internal process for assessing the capital adequacy to risks and the conditions of outsourcing their activities identifies the following major risks, with significant impact on the financial and reputational situation of the bank: compliance risk; interest rate risk; risk related information technology (IT); reputational risk; strategic risk; market risk; model risk; credit risk; country risk; transfer risk; liquidity risk; legal risk.

In the interest of monitoring, managing and evaluating such risks, credit institutions are constantly involved in the risk management process. Banking risk management encompasses all risk management processes and models meant to ensure the implementation of risk-based policies and practices, including techniques and management tools necessary to measure, monitor and control all risks faced by the credit institution. Risk-based policies and practices aim primarily at strengthening the risk profile and improving the efficiency of the bank's portfolio.

The responsibilities of the risk management function with respect to the management of risks faced by the bank are as follows:

- Continuous measurement of the risks related to the assets portfolio and other exposures;

- Communicating the risk profile of the bank to the concerned persons within the bank, to the supervisory authorities and to other relevant stakeholders;

- The adoption of measures, either directly or in conjunction with other banking functions to reduce the risk of a loss or to reduce the size of the potential loss.

The management of the credit institution is responsible for: the understanding the significant risks faced by the credit institution; the establishment of acceptable levels of those risks; ensuring that the necessary measures are taken to identify, measure, monitor and control those risks.

It is the role of internal audit to support the organization in pursuing its objectives, through a systematic 
approach, in order to assess and improve the effectiveness of risk management.

The modern approach of the internal audit is based on risk and provides for the chief audit executive to carry out an assessment of the organisation's risk, based on which the audit units are assessed; the frequency at which the units are audited is directly proportional to the risk associated with them.

The International Standards for the Professional Practice of Internal Auditing, specifically Standard 2120 Risk Management (IIA, 2012) stipulates the need for internal audit activities to determine the effectiveness and to support the improvement of risk management processes. In assessing the effectiveness of risk management processes, internal audit should consider the following:

- The objectives of the organisation support and are related to the mission;

- Major risks are identified and assessed;

- Risk responses are determined in order to harmonize the risks with the organization's risk appetite;

- Capturing and fast communicating within the organisation of important information regarding risk management enable the involved staff, the management and the board to carry out their responsibilities.

Internal audit can assess the processes' effectiveness based on information collected during several audit missions, which, considered together, can provide a representative perspective on the risk management process and its effectiveness.

In accordance with Standard 2120 (IIA, 2012), the assessments made by internal audit in relation to risk management involve the following:

- Assessing the risk exposures in relation to governance, operations and information systems of the organisation;

- Assessing the potential of fraud and the manner in which the risk of fraud is managed;

- During the advisory missions, approaching the significant risk in line with the objectives of the mission, and also paying attention to the existence of other significant risks;

- During the assistance missions for the establishment and improvement of risk management processes, internal auditors should refrain from assuming any

responsibility with regard to risk management.

Internal audit can have an important contribution in assisting the organization in its approach to overcome the difficulties arising from the encountered risks.

Through risk management, internal audit not only prevents the risks, but it helps the organization to function more efficiently as a result of a more structured and organized approach.

\subsection{Approaches regarding the value added and internal audit performance}

According to the definition provided in the Glossary to International Standards in the Glossary for the Professional Practice of Internal Auditing (IIA, 2012), "The internal audit activity adds value to the organization (and its stakeholders) when it provides objective and relevant assurance, and contributes to the effectiveness and efficiency of governance, risk management, and control processes."

The added value can be seen from the perspective of various stakeholders, namely: internal auditors/providers of internal audit services; board of directors/audit committee/superior management; supervisory authorities; other stakeholders.

Arena and Azzone (2009) aimed to determine the factors that influence the effectiveness of the internal audit activity. The study was conducted based on information collected from 153 Italian companies and shows that the effectiveness of the internal audit activity is influenced by:

- The characteristics of the audit team;

- The audit processes and activities;

- The relationships within the organization.

Thus, the effectiveness of the internal audit is positively influenced by:

- Increasing the ratio between the number of internal auditors and the number of employees of the organization;

- Affiliation of the CAEs to the IIA;

- Adoption by the organization of risk self-assessment techniques;

- Audit Committee's involvement in the activities of internal auditors. 
The study "Global Internal Audit Survey" conducted by the IIA (2010a) materialized in five reports incorporates the understanding and views of an important segment of practitioners in the area of internal audit, internal audit services providers and academics, with respect to the nature and purpose of the assurance and advisory activities specific to the internal audit profession worldwide, based on more than 13,500 responses available from respondents in over 107 countries.

The IIA (2011a) report "Measuring Internal Auditing's Value. Report III", focused on measuring the value provided to organization by the internal audit activity reveals that the value of the audit activity is expressed through the utility it shows for organization, appreciated in terms of perceived contribution of the internal audit activity. This perception is influenced by several factors, the most important being:

- Ensuring suitable access to the audit committee;

- Conducting the activity without the existence of any constraints regarding the modification of any rating assessment or the discarding of mentioning any deficiencies;

- Audit tools and technology used in the context of an audit mission.

IIA (2010b) endorsed the new value proposition of internal audit, expressing its vision on how the internal audit function provides value. According to this vision, "Governing bodies and senior management rely on Internal Auditing for objective assurance and insight on the effectiveness and efficiency of governance, risk management, and internal control processes."

In a broad sense, the term "insight" is defined as representing "the capacity to gain year accurate and deep intuitive understanding of a person or thing" (Oxford American Dictionary). IIA (2010b) believes that, for the internal audit profession, insight represents an key component of the Value Proposition, one of the main objectives of the internal audit function being to provide stakeholders with perspective achieved during the performed assessments, with regard to both the implications of such evaluations, and providing recommendations.

In 2011, the IIA assisted by Deloitte\&Touche launched the research project with the objective of determining the current status and expectations concerning the insight delivery by the internal audit; the project objectified with the report "Insight: Delivering Value to Stakeholders"
(IIA, 2011b), which highlights the following determinant factors for supplying insight by the internal audit:

- Provision by the organisation's management of a strong control environment, where the executive and operational management are totally open to recommendations for improvement;

- Board, management and CAEs to communicate clearly their expectations on providing value and insight by the internal auditors;

- CAE reporting relationship, namely ensuring the independence of the internal audit function;

- The existence of audit staff having practical skills and experience in the industry, which are needed to make the required correlations between the audit process and business risk management;

- Clear, constructive communication that offers understanding of the identified problems and the appropriate recommendations.

BCBS (2012) published the revised guide for assessing the effectiveness of the audit function in banks ("The Internal Audit Function in Banks"), which replaces the document form 2001 ("Internal Audit in Banks and the Supervisor's Relationship with Auditors"), and considers the lessons learned from the recent international financial crisis. The document focuses on the supervising authorities' expectations with regard to the internal audit function in banking institutions, the relationships between supervising authorities and this function and it provides a guide regarding the evaluation of the internal audit function by the supervisory authority.

Thus, from the supervisors' point of view, the periodic assessment of the internal audit function is supposed to determine whether it has the necessary capacity and authority and it operates in compliance with sound principles.

BCBS (2012) recommends the assessment of the internal audit function to be made considering the supervisors' expectations regarding this function, including the following items:

- Characteristics of internal audit function: independence and objectivity; professional competence; professional ethics;

- The status and authority of the internal audit function within the bank, which must report directly to the board of directors/audit committee, allowing the auditors to demonstrate objectivity in performing the engagements; 
- The existence and the provisions of the internal audit charter, which must highlight the status and authority of the internal audit function within the bank;

- The scope of the audit that should include reviewing and evaluating the effectiveness of the internal control, risk management and corporate governance systems and processes for the entire bank and to adequately cover the aspects of interest from the point of view of the audit plan objectives;

- Corporate governance mechanisms applicable to the internal audit function, such as: permanence, authority, status and independence of the internal audit function; adequate resources for the internal audit activity; direct access to the board of directors; existence of independent, competent and qualified audit staff;

- Organization of the internal audit function at group level, in the sense of providing a consistent internal audit approach in all the banks from the group;

- The level of competence, experience and expertise within the internal audit function, which means: the ability to collect, analyse and evaluate information and to communicate adequately with stakeholders; use of appropriate audit tools and techniques; good understanding of bank's activities;

- Structure of remuneration package at the level of the internal audit function, especially at the level of senior management and the key audit functions, which must be in line with the bank's policies and practices; the performance rewarding package should be structured so as to ensure the avoidance of conflicts of interest and of compromising the objectivity and independence;

- Outsourced internal audit activities, if this is the case.

Deficiencies identified by the supervisors with regard to the internal audit function may affect the assessment of the risk profile of the bank.

Applying the principles set out in the BCBS (2012) guide is carried out in compliance with national legislation and applicable corporate governance structures. BCBS (2012) also states that concurrently with the quality assessment of the internal audit function performed by the supervisory authority, the audit committee and the internal audit function in itself have a responsibility to develop and apply methods to assess the quality of the internal audit function.
The board of directors has the final responsibility to review the performance of the internal audit function; in this respect, the board should periodically perform an independent external assessment of the quality assurance for the internal audit function.

Deloitte (2014), one of the Big Four companies, which provide audit services for an important segment of public companies, conducted the study "Head of Internal Audit, Survey 2014. Capturing insight" by which it synthesized insights and observations with regard to the auditing practices in Ireland. The study was conducted with participants from various companies working in the fields of financial services (45\%), consumer and business technology $(24 \%)$ and in the public sector $(31 \%)$. It showed that, although every activity sector has specific features, there are many issues and challenges common to all fields. The Deloitte (2014) study highlighted the main challenges faced by internal audit in terms of expanding role the appearance of new risks, increasing control exercised by the stakeholders and in terms of resource pressures.

One of the core issues considered in the assessment of the internal audit function is represented by the performance assessment, including the way in which plans are carried out and how the review of the internal audit function at a general level is performed. The results of the study (Deloitte, 2014) emphasized the following: $97 \%$ of respondents confirm that the assessment of the internal audit performance is made according to a specific methodology, and $95 \%$ of respondents confirm that the methodology used is in accordance with the IIA standards. However, only $67 \%$ of respondents have confirmed that the methodology used includes a process of external quality assessment, given that the IIA standards require a quality assurance and improvement program, as well as internal and external quality assessments, with regular external assessment with a maximum frequency of five years.

Although there is an interest on the assessment of the internal audit function both on the side of the supervisory authorities and on the side of banks' management, expectations and quality assessment systems of the internal audit are particular for each function, depending on its specific objectives.

In terms of internal audit performance assessment methods used by the management, both the regulations applicable to the bank's internal audit function, as well as the applicable standards and guidelines state the 
responsibility of the management, audit committee and chief audit executives to assess the quality and performance of the internal audit function by establishing clear performance criteria and appropriate methods for measuring the achieved performance.

\section{Performance measurement of the internal audit function. Key performance metries}

As mentioned in the IIA (2011a) report "Measuring Internal Auditing's Value. Report III", the value of the internal audit activity is appreciated in terms of its perceived contribution to the governance and smooth running of the organization's activity. This perception is influenced directly by the assessment of the internal audit activity performance.

In a general sense, performance measurement can be regarded as "a metric used to quantify the efficiency and/or effectiveness of the action" (Neely, Gregory and Platts, 1995). The importance of measuring performance and performance indicators was evidenced by Flapper, Fortuin and Stoop (1996) as follows: "A good manager keeps track of the performance of the system he or she is responsible for by means of performance measurement. His/her staff carrying responsibility for certain activities within the performance measurement system, need to see how well they are performing their tasks. This also holds for the employees actually executing the various process steps. So performance indicators important for everyone inside year organisation, as they tell what has to be measured and what the control limits the actual performance should be within."

Regarding the importance of measurement, $H$. James Harrington (cited by Shimp, 2008) stated: "If you can't measure something, you can't understand it. If you can't understand it, you can't control it. If you can't control it, you can't improve it".

Therefore, it is apparent that performance measurement has a major importance for the process of assessment of the audit function, which provides it with the opportunity to find out where it stands in relation to the functions in other similar entities and to identify and adopt new practices to improve its results. Setting the performance indicators is of utmost importance to determine to what extent the audit function accomplishes its objectives, in accordance with the practices and standards of quality.

Considering the importance of internal audit performance measurement, a series of studies were conducted to understand the methods and practices used to measure the performance of the internal audit activity.

Performance measurement systems differ significantly between audit functions, as a result of the great diversity of organizations served by these functions (Rupsys and Boguslauskas, 2007). In practice there are various classifications of performance measurement systems used in internal audit. One of the most used systems is based on the balanced scorecard approach (Ziegenfuss, 2000), which shows the alignment of the audit department objectives and activities to those of the organization. In case of using this method, special attention should be given to the combinations of indicators/metrics which should be adapted to each category of stakeholders, as well as possible.

Another classification method is represented by the "input-process-output" method (Rupsys and Boguslauskas, 2007) where:

- Input may be represented by the auditors' and organization's qualities (experience, qualifications of personnel, approved budget; other factors);

- Process is represented by the whole process and all auditing activities;

- Results are the final outcome of the audit process, consisting in: assurance provided, counselling services, recommendations offered, the level of understanding provided, business process improvements made as a result of internal audit, etc.

The GAIN (2009) report "Measuring Internal Auditing Performance" synthesizes significant issues, recommendations and best practices of successful performance management from organizations that develop guidelines and from practitioners in the field of internal audit, as well as information from flash surveys and the "Annual Benchmarking Study".

According to IIA (2009) - "Annual Benchmarking Study", the main identified categories used to measure the performance of the internal audit are: the degree of satisfaction of stakeholders; internal audit processes and capacity for innovation. The main tools and techniques used for measuring these indicators are presented in Table 3: 


\section{Table 3. Indicators used to measure the performance of internal audit}

\begin{tabular}{|c|c|c|}
\hline $\begin{array}{l}\text { Overall ranking/ } \\
\text { category }\end{array}$ & $\begin{array}{l}\text { Performance } \\
\text { category }\end{array}$ & Tools/ technique used for measuring \\
\hline 1 & \multirow{3}{*}{$\begin{array}{l}\text { The degree of } \\
\text { stakeholders' } \\
\text { satisfaction }\end{array}$} & Surveys/ Stakeholders questionnaires \\
\hline 2 & & Interviews/ Stakeholders meetings \\
\hline 3 & & Key performance metrics/indicators \\
\hline 1 & \multirow[t]{3}{*}{$\begin{array}{l}\text { Internal audit } \\
\text { processes }\end{array}$} & $\begin{array}{l}\text { Adequate audit plans are established for each mission including: scope, objectives, } \\
\text { timing, resource allocation }\end{array}$ \\
\hline 2 & & Conducting audits in compliance with established methodologies and practices \\
\hline 3 & & $\begin{array}{l}\text { The feedback obtained from key stakeholders regarding the extent to which the audit } \\
\text { effectively addresses the problem of the risks }\end{array}$ \\
\hline 1 & \multirow{3}{*}{$\begin{array}{l}\text { Innovation and } \\
\text { capacity }\end{array}$} & Implementation of measures by which to provide appropriate training of audit staff \\
\hline 2 & & Measuring the number of certifications held by the audit staff \\
\hline 3 & & Implementation of measures that ensure the achievement of mission goals and objectives \\
\hline
\end{tabular}

Source: Author's processing based on the results form "Knowledge Report. Measuring Internal Auditing Performance", GAIN, 2009

Although the indicators used to measure internal audit performance differ from one organization to another, various studies performed by the IIA, including the GAIN (2009) study have synthesized several important indicators used regardless of organization, namely:

- making surveys/questionnaires with stakeholders;

- audit missions carried out versus the ones planned;

- complying with the definition of internal auditing, standards and code of ethics.

The conclusion is that, regardless of audit methods and techniques used, it is necessary for audit leaders to select the audit methodology and performance indicators that best fit the object of the audit activity, taking into account the expectations of the various stakeholders, including the audit committee and management team, thus ensuring that audit efforts are aligned with the strategic objectives of the organization and add value to it.

The report "Measuring Internal Auditing's Value. Report III" (IIA, 2011a) also showed differences in the use of performance measuring methods both between regions and industries. The ranking of the most commonly used methods for assessing the performance of the internal audit activity in the financial industry, which includes the banking sector, compared with the methods used in all industries is presented in Table 4.

\begin{tabular}{|c|c|c|}
\hline Methods & $\begin{array}{c}\text { Total } \\
\text { (all industries - \%) }\end{array}$ & $\begin{array}{l}\text { Financial industry } \\
(\%)\end{array}$ \\
\hline Percentage of completed audit plans & 13,7 & 12,3 \\
\hline Recommendations accepted/implemented & 11,8 & 9,2 \\
\hline Surveys/feedback from the board, audit committee, and/or senior management & 10,8 & 9,1 \\
\hline Customer/auditee surveys from audited departments & 9,1 & 7,3 \\
\hline Assurance of sound risk management/internal control & 8,3 & 6,9 \\
\hline Reliance of external auditors on the internal audit activity & 8,3 & 8,0 \\
\hline Timely closure of audit issues & 7,6 & 6,2 \\
\hline Completion of mandated coverage & 7,0 & 6,3 \\
\hline Number of significant audit findings & 6,6 & 4,1 \\
\hline Budget to actual audit hours & 6,3 & 5,8 \\
\hline Number of management requests for internal audit assurance or consulting projects & 5,8 & 4,1 \\
\hline $\begin{array}{l}\text { Cost savings/avoidance and improvements due to the implemented } \\
\text { recommendations }\end{array}$ & 5,7 & 3,6 \\
\hline Cycle time - report turnaround (end of fieldwork to final report) & 5,1 & 3,5 \\
\hline Balanced scorecard & 4,1 & 3,6 \\
\hline Cycle time from the opening conference to a preliminary report draft & 4,1 & 3,5 \\
\hline Absence of regulatory or reputation issues and significant failures & 3,8 & 4,4 \\
\hline
\end{tabular}

Source: Author's processing based on results of IIA (2011a) study "Measuring Internal Auditing's Value. Report III 
From the analysis of trends in the methods used for assessing the internal audit performance, it resulted that the first five most commonly used methods at the time of the study will maintain their importance during the next five years, along with the recently added balanced scorecard method, of growing importance.

The study also highlighted the fact that:

- There is a correlation between the methods employed by the internal audit activity to measure its performance and their perceived contribution. Methods with the highest correlation coefficients are: the implementation percentage of the audit plan; recommendations accepted/implemented and questionnaires/feedback of the board of directors, audit committee and senior management. These methods are the most representative and resultoriented regarding the contribution of internal audit activity to improvement the organizational processes.

- There is a direct correlation between the scope of internal audit activities and their perceived contribution. There is a higher correlation between the internal audit activities on internal control, governance and risk management, on the one hand, and the perceived contribution of internal audit to the improvement of these processes, on the other hand.

PricewaterhouseCoopers, one of the Big Four audit companies, published in September 2014 the study "Metrics by design. A practical approach to measuring internal auditing performance", referring to the way in which all internal audit functions, regardless of the organization in which they operate, can generate indicators with which to communicate the value supplied and monitor performance (PwC, 2014b). The study results reflect the relative low stakeholders' perception regarding internal audit, implying either that the internal audit is unable to keep up with the changes taking place in the environment, or that it fails to report the real value delivered with the used indicators. After a deeper analysis, there was found at the same time a significant difference between the perceived value in the case of the audit functions characterised by a higher share of "Trusted advisors" type audit services, as compared with those performing more traditional "Assurance providers" type services.

The difference between perceived performance under the two approaches is presented in Table 5.

\begin{tabular}{|l|c|c|}
\hline \multicolumn{1}{|c|}{ Table 5. Internal audit performance of "Trusted advisors" compared to "Assurance providers" services } \\
\hline \multicolumn{1}{|c|}{ Key performance metrics } & \multicolumn{2}{c|}{$\begin{array}{c}\text { Percentage of respondents who indicate that internal } \\
\text { audit performance is good }\end{array}$} \\
\hline $\begin{array}{l}\text { Focus on critical risks and problems encountered by the } \\
\text { organization }\end{array}$ & "Trusted advisors" & $53 \%$ \\
\hline Goal and audit plan alignment to stakeholders' expectations & $83 \%$ & $64 \%$ \\
\hline Promoting improvements in quality and innovation & $73 \%$ & $29 \%$ \\
\hline Hiring, training, and/or selecting talents for audit & $68 \%$ & $45 \%$ \\
\hline Effectively use of technology in auditing services & $51 \%$ & $29 \%$ \\
\hline
\end{tabular}

Source: Author's processing based on the results of the study, "Metrics by design. A practical approach to measuring internal audit performance", PwC, 2014

The study reveals that there is no unique set of "best practice" metrics for performance measurement. The management of the audit function is used to generate their own indicators that meet the requirements of the mandate (mission, vision, strategy) and the

stakeholders' expectations. The continuous updating of the performance indicators ensures the reporting of the real value provided by the audit function, in accordance with both the evolutions of the audit function and with the changing risk profile of the organization. In addition, the audit functions that generate indicators expressing the real value provided to stakeholders and correlate performance indicators with stakeholders' expectations manage to attract superior appreciation from stakeholders.

The PwC (2014) study also specifies that making a "balanced scorecard" of the performance indicators only represents the beginning of the transformation 
process necessary for the internal audit function. In order to obtain a "balanced scorecard" containing relevant indicators, cultural transformations may be needed, as well as the development of a communication plan to describe the expectations adequately.
The objective of the audit functions management should not be limited to the indicators which reflect the delivery of superior results. It is necessary for the balanced scorecard to include some important fields, such as: the processes' effectiveness, personnel, risk coverage, as presented in Table 6.

\section{Table 6. Illustration of metrics for the balanced scorecard}

\begin{tabular}{|c|c|c|c|}
\hline \multicolumn{4}{|c|}{ Illustrative internal audit balanced scorecard } \\
\hline$\frac{\text { D }}{\frac{N}{>}}$ & $\begin{array}{l}\text { - \% of audits and SOX testing completed within schedule } \\
\text { and on budget } \\
\text { - \% of completed audits that utilized data analytics } \\
\text { - End of audit client satisfaction survey results }\end{array}$ & $\begin{array}{l}\text { - Business process improvements resulting from } \\
\text { internal audit } \\
\text { - Level of management requested involvement } \\
\text { with strategic initiatives } \\
\text { - Stakeholder assessment and feedback } \\
\text { compared with expectations } \\
\text { - Level of insight and proactive advice delivered } \\
\text { - Training sessions or involvement with } \\
\text { enhancing internal control/risk management } \\
\text { knowledge of the organization }\end{array}$ & 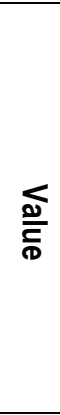 \\
\hline 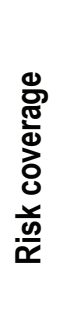 & $\begin{array}{l}\text { - \% of the audit plan aligned to major risk categories (i.e., } \\
\text { financial, operational, strategic, etc.) } \\
\text { - \% of non-IT versus IT audit missions included in the } \\
\text { plan }\end{array}$ & $\begin{array}{l}\text { - Visual representation of alignment of audit plan } \\
\text { to individual enterprise risks } \\
\text { - Level of focus on emerging risks or } \\
\text { transformational initiatives } \\
\text { - Alignment and coordination with other } \\
\text { compliance functions (i.e., enterprise risk } \\
\text { management, SOX compliance, } \\
\text { legal/compliance, etc.) }\end{array}$ & 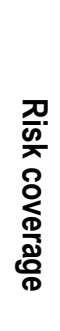 \\
\hline$\frac{\Phi}{\stackrel{0}{\circ}}$ & $\begin{array}{l}\text { - \% of internal audit staff with relevant certifications } \\
\text { - \% of IT versus non-IT staff } \\
\text { - Internal audit department turnover } \\
\text { - Departmental headcount compared to budget }\end{array}$ & $\begin{array}{l}\text { - Alignment of talent to enterprise risks } \\
\text { - Leverage of subject matter specialists and } \\
\text { guest auditors } \\
\text { - Placement of internal audit staff into advanced } \\
\text { internal audit positions or rotation within the } \\
\text { business }\end{array}$ & $\frac{\text { D }}{\frac{0}{0}}$ \\
\hline 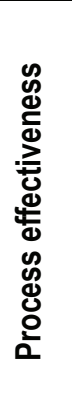 & $\begin{array}{l}\text { - Overall internal audit department budget compared to } \\
\text { the prior period } \\
\text { - Number of audits completed within the budgeted time } \\
\text { - Audit report findings by status and division } \\
\text { - Audit report ratings issued during the period } \\
\text { - Number of days from fieldwork to report } \\
\text { - \% of audit missions with internal quality review } \\
\text { performed by the end of fieldwork }\end{array}$ & $\begin{array}{l}\text { - Services cost-effectiveness ratio } \\
\text { - } \% \text { of audit missions where tools were provided } \\
\text { to the business (i.e., data analytics, } \\
\text { dashboards, databases, continuous auditing } \\
\text { routines, thought leadership, etc.) } \\
\text { - Number of audit findings remediated before the } \\
\text { issuance of the audit report } \\
\text { - } \% \text { of audit missions using data analytics to } \\
\text { drive decisions - resulting in reductions of audit } \\
\text { workhours }\end{array}$ & 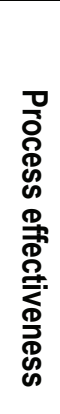 \\
\hline Assu & Problem solver & Insight generator & \\
\hline
\end{tabular}

Source: "Metrics by design. A practical approach to measuring internal audit performance", PwC, 2014 
As benefits of using the balanced scorecard, there are mentioned:

- Harmonizing the strategy and internal audit activities with stakeholders' expectations;

- Offering an extensive picture regarding performance;

- Allowing comparative analyses in relation to the reference indicators (benchmarking);

- Improving final results through cost reductions and streamlining processes.

Additionally, communicating metrics involves a very good understanding of the audience, as well as the adaptation of methods, frequency and approach used in the report to stakeholders' needs. The preparation and processing of the necessary data, as well as the presentation of metrics require the use of technology and human resources with the appropriate competences.

Finally, success in highlighting the achievements of interest for the audience depends on the tools used to report metrics, namely the dashboard and data visualization.

\section{Practices supporting the growth of value provided by internal audit}

Various recent studies ("Insight: Delivering Value to Stakeholders" - IIA, 2011b; "2014 State of the Internal Audit Profession Study - PwC, 2014a) summarize a number of examples of original and compelling practices that foster the increase of value provided by the internal audit, among which we mention:

\section{Assessing internal audit performance by} reviewing audit services in case an operational loss is identified, for the purpose of determining if there were any weaknesses of the internal audit process that need to be corrected, also capitalizing this as an opportunity for better understanding the real risks of the business (IIA, 2011b).

2. Organizing an assurance forum consisting of people with an important role in the organization's risk management (chief risk officer - CRO, compliance and ethics, chief information officer $\mathrm{CIO}$, finance - $\mathrm{CFO}$ and auditing - $\mathrm{CAE}$ ), including the external auditor: Within the forum, there can be discussed: the risks faced by the organization; adverse risk events and their causes; the results of activities performed in order to ensure decreases of risks; identification of delays in assurance and monitoring activities; appointing managers in charge with monitoring and risk assessment; appropriate methods used for the communication of risk issues to the board of directors/executive directors (IIA, 2011b).

3. Stakeholder commitment to ensuring a reporting relationship which supports the independence of the internal audit function (IIA, 2011b).

4. Ensuring the existence of IT expertise and internal audit skills necessary for achieving of data analyses and to harness useful and effective financial and operational information, providing insight with regard to operational results and helping the management to develop the activity more efficiently and more effectively (IIA, 2011b).

5. Use of benchmarking, namely: providing the management with comparative analyses regarding the operations of the various locations of the organization, using automated testing on the basis of standard queries and periodical data analyses; results summarization and creating a balance scorecard. In this way, it is possible the prompt identification of the exceptions and variations from the standards of the organization, making action plans to remedy the identified deficiencies and to follow-up (IIA, 2011b). This allows internal audit to obtain a greater coverage with fewer resources, while also providing to the management comparative data analyses corresponding to the already improved operational results.

6. Existence of clear audit missions, focused on providing value, according to the business strategy of the organization (the IIA, 2011b), which involves:

- Establishing a standard internal process and a work methodology;

- Identification and confirmation of the stakeholders' expectations and requirements;

- Development of effective communication strategies;

- IT involvement into the audit process;

- Human resources training and orientation. 


\section{Providing quantifiable results and} recommendations, which enable the management to assess correctly the cost/benefit ratio of the proposed action plans and to support the rationale for the cost of putting them into practice (IIA, 2011b).

8. Harmonizing internal audit activities with stakeholders' strategies, in order to provide insight into the board of directors' and management' areas of interest (IIA, 2011b).

9. Permanent investments in innovative solutions, adapted to the ever changing environment, concurrently with the focus on advisory missions and services that analyse adverse and favourable risks, thus supporting the management to take into account the necessary controls and risks involved in the processes, even before defining a product. By adopting innovative solutions, it is possible to stimulate the use of data analysis in order to increase the efficiency of retrospective audit missions and allocate more time for prospective audit missions, where management finds the higher value delivered by internal audit (PwC, 2014a).

10. Focusing on including in the audit reports the fundamental control deficiencies and causes, as opposed to communicating exceptions. This involves changing the auditors' way of thinking and including within audit teams experienced audit executives, who can ensure the development of auditors' skills in the functional areas (PwC, 2014a).

11. Using continuous improvement methodologies, such as Six Sigma, in order to increase internal audit performance, by improving the understanding about how processes can be controlled and the collaboration between auditors and auditees, resulting in a better acceptance of findings and recommendations issued by the internal audit. Using such methodologies of continuous improvement involves the consideration of only those aspects relevant to internal audit (PwC, 2014a).

The studies highlighted the fact that those audit leaders who have the possibility and the resources needed to deliver according to the strategic objectives present a higher importance for the organizations in which they operate and stakeholders confirmed that they benefit from higher value delivered by internal audit. For this reason, the audit leaders need to project the audit functions properly, based on collaboration and getting consensus regarding stakeholders' expectations. Considering the complex and dynamic risk environment in which most organizations operate, the board of directors and the superior management should also get involved in the design of the internal audit function and support the necessary investment in the development of internal audit capabilities, encouraging its orientation towards delivering value for the organization.

\section{Conclusions}

In the last decades, significant changes have occurred in terms of attention paid to the assessment of the value added, effectiveness and performance of the internal audit activity. Recent studies show that both banking institutions and supervisory authorities want the extension of the internal audit contribution, in order to add more value to the organizations' operations and contribute to achieving their objectives, by means of a more active role in risk management and corporate governance.

Executive management expects more than providing credible assurance and efficient audit missions, because it wants to be able to call on the internal audit in case of strategic initiatives for which there are needed both expertise and insight, as well as providing ideas that represent challenges to the current practices of the organization and can lead to continuous improvement of the performance.

Internal audit can assist the banking institutions in achieving the necessary changes and to identify the optimal balance between risk, cost and value. To enjoy success, appreciation and authority, it is not enough for internal audit to present the results of the audit mission, but it important to engage the executive management and the members of the board of directors in the careful analysis of the current business issues and in supporting the development of strategies which address the business risks. In addition, considering the rapid developments in technology, chief audit executives must ensure that the potential offered by the data analysis tools is harnessed, in order to decide what to audit, to audit the processes efficiently and monitor operational risks appropriately, while offering insight to the management and board of directors and even new and permanent tools for the assessment of operations.

In turn, the banking supervisory authorities periodically evaluate the banking internal audit functions to 
determine whether they have the capacity and the necessary authority and operate in conformity with sound principles. The banking supervisors must be satisfied with the effectiveness of the internal audit function of the bank with regard to compliance with policies and practices, and the adoption of appropriate measures to remedy the deficiencies identified by internal audit.

In order to determine the extent to which the audit function accomplishes its objectives and responds to stakeholders' expectations, it is required to measure its performance. Although there are differences between the metrics used for measuring the performance of internal audit depending on the specifics of each organization, the achieved studies have pointed out the following successful practices used for performance measurement:

- Conducting customers' or stakeholders' satisfaction surveys;

- Tracking the completed versus the planned number of audit assignments;

- The extent to which the compliance of performance metrics with the definition of internal auditing, standards and Code of Ethics is ensured;
- Use of balanced scorecard to determine whether audits contribute to adding value and improve the overall performance of the organization.

Considering the role of internal audit in assessing and improving the effectiveness of risk management processes, we believe that the value added by the internal audit to the organisation must be considered also in terms of its contribution to reducing the risk of losses or to reducing the potential losses, and, respectively, to improving the risk profile of the credit institution.

Regardless of the tools and techniques used to measure the performance of the internal audit, the chief audit executives should select the methodology of performance measuring that best fits the characteristics and objectives of auditing activity.

In addition, prior to the selection of metrics for performance measurement, the leaders of the audit functions need to take into consideration the key stakeholders' expectations. In this way, it will be possible not only to measure the internal audit performance, but also to harmonize audit activities with the strategic goals of the banking institutions and increase the value added by the internal audit.

\section{REFERENCES}

1. Arena, M. and Azzone, G. (2009), Identifying Organizational Drivers of Internal Audit Effectiveness, International Journal of Auditing, vol. 13, no. 1, pp. 43-60, DOI: http://dx.doi.org/10.1111/j.10991123.2008.00392.x.

2. BCBS (1998), Framework for Internal Control Systems in Banking Organisations, [pdf] Available at: http://www.bis.org/publ/bcbs40.pdf, [Accessed on August 2, 2016].

3. BCBS (2001), Internal Audit in Banks and the Supervisor's Relationship with Auditors, [online] Available at: http://www.bis.org/publ/bcbs84.htm [Accessed on August 2, 2016].

4. BCBS (2012), The internal audit function in banks, [pdf] Available at: http://www.bis.org/publ/bcbs223.pdf, [Accessed on August 2, 2016].
5. BCBS (2015), Guidelines. Corporate governance principles for banks, [pdf] Available at: http://www.bis.org/bcbs/publ/d328.pdf, [Accessed on August 2, 2016].

6. BNR (2013), Regulamentul BNR nr. 5/2013 privind cerințe prudențiale pentru instituțiile de credit, Monitorul Oficial Nr. 841 din 30 decembrie 2013.

7. Deloitte (2014), Head of Internal Audit Survey 2014. Capturing insight, [pdf] Available at: http://www2.deloitte.com/content/dam/Deloitte/ie/D ocuments/Audit/2014_internal_audit_survey_deloitt e_ireland.pdf, [Accessed on August 2, 2016].

8. Directive 2006/48/EC of the European Parliament and of the Council of 14 June 2006 relating to the taking up and pursuit of the business of credit institutions (recast), Official Journal of the European Union, 30.06.2006, L111/1.

9. Directive 2013/36/EU of the European Parliament and of the Council of 26 June 2013 on access to 
the activity of credit institutions and the prudential supervision of credit institutions and investment firms, amending Directive 2002/87/EC and repealing Directives 2006/48/EC and 2006/49/EC, Official Journal of the European Union, 27.06.2013, L176/338.

10. Ernst \& Young (2010), Unlocking the strategic value of Internal Audit; Three steps to transformation, [pdf] Available at: http://images.forbes.com/forbesinsights/StudyPDFs Unlocking_Strategic_Valueoflnternal_Audit.pdf, [Accessed on August 2, 2016].

11. Flapper, S.D.P., Fortuin, L. and Stoop, P.P.M. (1996), Towards consistent performance management systems, International Journal of Operations \& Production Management, vol. 16, no. 7, pp. 27-37, DOI: http://dx.doi.org/10.1108/01443579610119144.

12. GAIN (2009), Knowledge Report. Measuring Internal Audit Performance, [pdf] Available at: http://www.felaban.net/archivos_boletines_clain/arc hivo20140723201321PM.pdf, [Accessed on August 2, 2016].

13. IIA (2010a), Global Internal Audit Survey, [online] Available at: https://global.theiia.org/about/aboutinternal-auditing/pages/global-internal-auditsurvey.aspx, [Accessed on August 2, 2016].

14. IIA (2010b), Value Proposition of Internal Auditing and the Internal Audit Capability Model, [pdf] Available at: https://na.theiia.org/standardsguidance/Public\%20Documents/SG\%20$\% 20$ Value $\% 20$ Proposition $\% 20$ of $\% 20$ IA $\% 20$ and $\% 2$ Othe\%20IA\%20Capability\%20Model.pdf, [Accessed on August 2, 2016].

15. IIA (2011a), Measuring Internal Auditing's Value. Report III, [pdf] Available at: http://www.hiir.hr/UserDocsImages///Measuring\%2 OIA\%20Value.pdf, [Accessed on August 2, 2016].

16. IIA (2011b), Insight: Delivering Value to Stakeholders, [pdf] Available at: https://www.theila.org/bookstore/downloads/freetoa II/IA\%20INSIGHT\%20REPORT\%20Final\%20for $\%$ 20Web.pdf, [Accessed on August 2, 2016].

17. IIA (2011C), Imperatives for Change: The IIA's Global Internal Audit Survey in Action. Report V, [pdf] Available at: https://na.theiia.org/iiarf/Public\% 20Documents/2010-CBOK-Imperatives-forChange.pdf, [Accessed on August 2, 2016].
18. IIA (2012), Glossary, [online] Available at: https://na.theila.org/standards-

guidance/mandatory-guidance/Pages/StandardsGlossary.aspx, [Accessed on August 2, 2016].

19. IIA (2012), International Standards for the Professional Practice of Internal Auditing, Standard 2120 Risk Management, [pdf] Available at: https://na.theiia.org/standards-

guidance/Public\%20Documents/IPPF\%202013\% 20English.pdf, [Accessed on August 2, 2016].

20. Neely, A., Gregory, M. and Platts, K. (1995), Performance measurement system design: a literature review and research agenda, International Journal of Operations \& Production Management, vol. 15, no. 4, pp. 80-116, DOl: http://dx.doi.org/10.1108/01443579510083622.

21. Ordonanța de Urgență a Guvernului nr. 99/2006 privind institutiile de credit și adecvarea capitalului, Monitorul Oficial Partea I, nr.1027/27.12.2006, cu modificările și completările ulterioare.

22. PwC (2014a), 2014 State of the Internal Audit Profession Study, [pdf] Available at: https://www.pwc.com/m1/en/publications/docume nts/pwc-state-of-the-internal-audit-profession2014.pdf, [Accessed on August 2, 2016].

23. PwC (2014b), Metrics by design. A practical approach to measuring internal audit performance, [pdf] Available at: https://www.pwc.com/us/en/risk-assuranceservices/publications/assets/internal-auditperformance-metrics.pdf, [Accessed on August 2, 2016].

24. Rupsys, R. and Boguslauskas, V. (2007), Measuring Performance of Internal Auditing: Empirical Evidence, Engineering Economics, vol. 55, no. 5, pp. 9-14, [pdf] Available at: http://www.inzeko.ktu.lt/index.php/EE/article/view/ 11495/6193, [Accessed on August 2, 2016].

25. Shimp, T.A. (2008), Advertising Promotion and Other Aspects of Integrated Marketing Communications, Mason: Cengage Learning.

26. Ziegenfuss, D.E. (2000), Measuring performance, Internal Auditor, [pdf] Available at: https://www.highbeam.com/doc/1G162599893.html , [Accessed on August 2, 2016]. 